\title{
Erratum to: Managing Corporate Sustainability with a Paradoxical Lens: Lessons from Strategic Agility
}

\author{
Sarah Birrell Ivory ${ }^{1} \cdot$ Simon Bentley Brooks ${ }^{2}$
}

Published online: 4 September 2017

(C) The Author(s) 2017

\section{Erratum to: J Bus Ethics \\ DOI 10.1007/s10551-017-3583-6}

The original article was incorrectly published without open access and with the copyright notice indicating ' $\odot$ Springer Science+Business Media Dordrecht'. The article is now open access with the copyright residing with the authors.

The online version of the original article can be found under doi:10.1007/s10551-017-3583-6.

Sarah Birrell Ivory

sarah.ivory@ed.ac.uk

Simon Bentley Brooks

s.b.brooks@swansea.ac.uk

1 University of Edinburgh Business School, Edinburgh, UK

2 Swansea University School of Management, Swansea, UK 